\title{
Long-term associations of outdoor air pollution with mortality in Great Britain
}

\section{Paul Elliott, Gavin Shaddick, Jonathan C Wakefield, Cornelis de Hoogh, David J Briggs}

Thorax 2007;62:1088-1094. doi: 10.1136/thx.2006.076851

See end of article for authors' affiliations

\section{Correspondence to}

Professor P Elliott, Small

Area Health Statistics Unit,

Department of Epidemiology

and Public Health, Faculty of

Medicine, St Mary's

Campus, Imperial College

London, Norfolk Place,

London W2 IPG, UK;

p.elliott@imperial.ac.uk

Received 22 December 2006

Accepted 16 June 2007

\begin{abstract}
Background: Recent studies have indicated long-term effects on mortality of particulate and sulphur dioxide $\left(\mathrm{SO}_{2}\right)$ pollution, but uncertainties remain over the size of any effects, potential latency and generalisability. Methods: A small area study was performed across electoral wards in Great Britain of mean annual black smoke (BS) and $\mathrm{SO}_{2}$ concentrations (from 1966) and subsequent all-cause and cause-specific mortality using random effect models within a Bayesian framework adjusted for social deprivation and urban/rural classification. Different latencies and changes in associations over time were assessed.

Results: Significant associations were found between $\mathrm{BS}$ and $\mathrm{SO}_{2}$ concentrations and mortality. The effects were stronger for respiratory illness than other causes of mortality for the most recent exposure periods (shorter latency times) and most recent mortality period (lower pollutant concentrations). In pooled analysis across four sequential 4 year mortality periods (1982-98), adjusted excess relative risk for respiratory mortality was $3.6 \%(95 \% \mathrm{Cl} 2.6 \%$ to $4.5 \%)$ per $10 \mu \mathrm{g} / \mathrm{m}^{3}$ BS and $13.2 \%(95 \% \mathrm{Cl} 11.5 \%$ to $14.9 \%)$ per $10 \mathrm{ppb} \mathrm{SO}$, and in the most recent period (1994-8) it was $19.3 \%(95 \% \mathrm{Cl} 5.1 \%$ to $35.7 \%)$ and $21.7 \%(95 \%$ $\mathrm{Cl} 2.9 \%$ to $38.5 \%$ ), respectively.

Conclusions: These findings add to the evidence that air pollution has long-term effects on mortality and point to continuing public health risks even at the relatively lower levels of $\mathrm{BS}$ and $\mathrm{SO}_{2}$ that now occur. They therefore have importance for policies on public health protection through regulation and control of air pollution.
\end{abstract}

W hile time series studies have indicated short-term associations between ambient air pollution and mortality, ${ }^{1}$ long-term effects on mortality are less well understood, although potentially more important for public health. $^{2}$ Early studies of long-term effects were mainly ecological in design across large geographical areas. ${ }^{3}$ More recently, cohort or case-control studies with individual level health data have investigated these effects for a range of pollutants including particle mass (eg, total suspended particles, $\mathrm{PM}_{10}$ or $\left.\mathrm{PM}_{2.5}\right)$, black smoke (BS), nitrogen oxides $\left(\mathrm{NO}_{\mathrm{x}}\right.$, $\left.\mathrm{NO}_{2}\right)$, ozone, sulphates and sulphur dioxide $\left(\mathrm{SO}_{2}\right)$. Although some studies have used exposure data modelled at the individual level, ${ }^{5-11}$ most involved a semi-individual design ${ }^{12}$ in which fixed site air pollution measurements were extrapolated to give city-wide or regional averages, with data on potential confounders available at the individual level. ${ }^{13-23}$ In most cases the air pollution estimates covered relatively short periods, either slightly before or concurrent with the mortality data. Few studies investigated potential latency effects ${ }^{14} 161924$ or explored changes in associations between air pollution and mortality over time..$^{14} 181921$

We report here associations between mortality and concentrations of $\mathrm{BS}$ and $\mathrm{SO}_{2}$ based on measurements from the dense national network of air monitoring sites in Great Britain. The aim was to quantify the patterns of geographical associations at the small area (local) scale for different exposure latencies and over time, in the context of declining air pollution concentrations.

\section{METHODS}

\section{Study design}

The study design is summarised in fig 1 . The study population comprised people aged $30+$ years and analysis was at the electoral ward level; the mean (SD) study population was 5301 (2560) and the mean (SD) area was $7.4(15.1) \mathrm{km}^{2}$. To provide stable small area mortality data, we summed deaths over four successive 4 year "mortality periods" from April 1982-March 1986 through to April 1994-March 1998. Exposure indices were similarly averaged over 4 year periods from April 1966-March 1970 to April 1990-March 1994 to smooth out year-to-year fluctuations in pollutant concentrations and minimise the effects of gaps in the monitoring data. Associations were analysed between mortality in each of the "mortality periods" and average annual air pollution for four preceding 4 year "exposure windows" of 0-4, 5-8, 9-12 and 13-16 years, giving latencies of up to $8,12,16$ and 20 years, respectively.

\section{Pollution data}

We obtained locations ( $10 \mathrm{~m}$ resolution) and annual average concentrations of $\mathrm{BS}\left(\mu \mathrm{g} / \mathrm{m}^{3}\right)$ and $\mathrm{SO}_{2}(\mathrm{ppb})$ for monitoring sites operating between April 1966 and March 1994 (inclusive) from the Great Britain air quality archive (www.airquality.co. uk). Sites were selected only if they were located in areas defined within the site records as wholly or partially residential. To provide ward level exposure indices, site locations were intersected with 1991 ward boundaries in a Geographical Information System and a single measure per ward was calculated for each 4 year exposure window, starting in 196670 and finishing in 1990-4. While most wards contained only one site, 76 contained two or more. The national monitoring network is not fixed so individual sites were closed, opened or moved at different times, both because of rationalisation of the network and in response to changing levels of air pollution. To provide a consistent and, as far as possible, continuous data set for exposure assessment, site records were joined "end on" where one site simply replaced another in the same ward; where two or more sites operated concurrently in the same

Abbreviations: ACS, American Cancer Society; BS, black smoke; PM, particulate matter; $\mathrm{SO}_{2}$, sulphur dioxide 


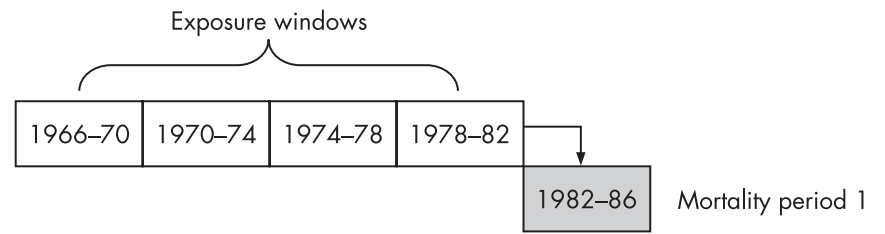

Figure 1 Outline of study design. Exposure windows and mortality periods run from April 1 to March 31 in the relevant years.

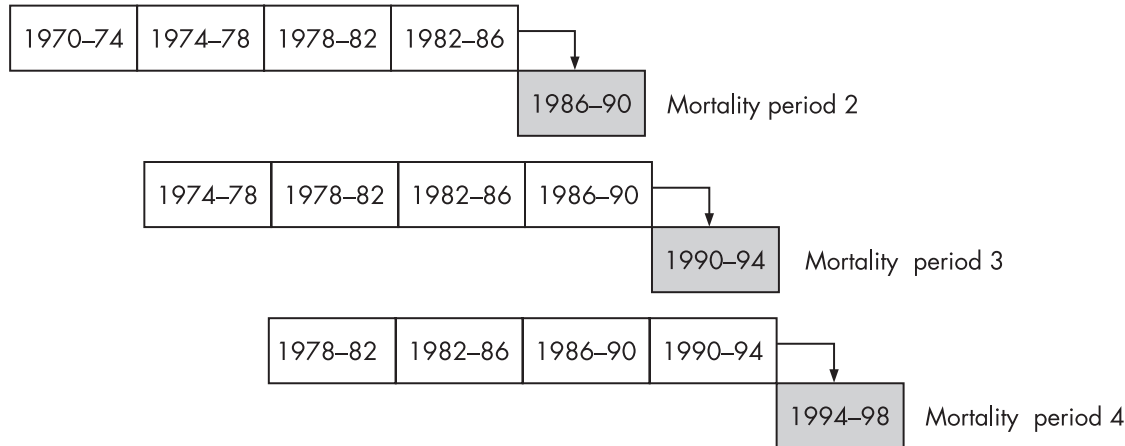

ward, the series with the longest and most complete run of data was used (or one site was selected randomly if the series were of the same length). We selected wards for analysis only if they had at least $75 \%$ daily data capture during at least 2 years in each of the 4 year exposure windows. This approach gave a consistent set of wards associated with each mortality period (fig 1). We also examined data for a subset of these wards $(n=63)$ for which air pollution data were available for the whole study period.

\section{Population and socioeconomic data}

Population counts (by age and sex) were obtained for each ward from the 1991 census. In the absence of individual measures of socioeconomic status, the Carstairs score was computed to provide a composite area level measure of social deprivation based on four census variables: social class, overcrowding, car ownership and unemployment. ${ }^{25}$ The Carstairs score was standardised to have mean 0 and standard deviation of 1 across wards in Great Britain.

Wards were classified as urban or rural by discriminant analysis to extrapolate the Countryside Agency classification of rural wards 1998-91 based on the satellite-derived Land Cover Map of Great Britain. ${ }^{26}$

\section{Mortality data}

Mortality data, stratified by age (30+ and 65+ years) and sex, were obtained from the national mortality database for all causes, cardiorespiratory disease (International Classifications of Disease version 9, 390-519), cardiovascular disease (390459), respiratory disease (460-519), lung cancer (162) and all other causes. Mortality data were linked to the relevant 1991 wards by residential postcode (average approximately 12 residential properties) and aggregated for each 4 year mortality period.

\section{Statistical analysis}

Variation in pollutants across wards and over time was explored by correlation and variance components analyses. Expected mortality rates (standardised by age and sex) were calculated for each ward using national mortality rates for the appropriate period. Observed deaths for each ward were modelled as Poisson, with a log-linear function for pollutant concentration, and a (log-normal) random intercept to allow for possible overdispersion in the Poisson model. We estimated excess relative risks for each cause of death for all mortality periods combined and for each period separately in relation to average pollutant concentrations in the immediately preceding 4 year exposure window (0-4 years), and then separately with each of the preceding windows $(5-8,9-12$ and $13-16$ years). Excess relative risks were also estimated for exposure windows of progressively increasing duration $(0-8,0-12,0-16$ years $)$. To capture socioeconomic contrasts between wards, including the possibility of non-linearity, Carstairs scores were categorised into study-specific deciles. Analyses were conducted both without and with adjustment for deprivation and urban/rural classification for each pollutant. Joint models for the two pollutants together were also run. Quadratic terms were fitted to check for non-linearity. Primary analyses were done for the population aged $30+$ years and selected analyses were repeated for those aged $65+$ years.

Models were fitted within a Bayesian framework using Markov chain Monte Carlo methods. The results were robust to choice of priors. Owing to the possibility of residual spatial correlation (ie, mortality for wards in close proximity being more similar than for distant wards), selected models were

Table 1 Characteristics of the study wards in comparison to Great Britain for each of four mortality periods

\begin{tabular}{|c|c|c|c|c|c|c|c|c|c|c|c|}
\hline \multicolumn{2}{|c|}{ Mortality period } & \multirow[b]{2}{*}{$\begin{array}{l}\text { No. of } \\
\text { wards }\end{array}$} & \multirow[b]{2}{*}{$\begin{array}{l}\% \text { urban } \\
\text { area }\end{array}$} & \multirow[b]{2}{*}{$\begin{array}{l}\text { Carstairs score } \\
\text { Median (IQR) }\end{array}$} & \multirow{2}{*}{$\begin{array}{l}1991 \text { census } \\
\text { population } \\
\text { (30+ years) }\end{array}$} & \multicolumn{6}{|c|}{ Number of deaths } \\
\hline No. & Years & & & & & All cause & $\begin{array}{l}\text { Cardio- } \\
\text { respiratory }\end{array}$ & $\begin{array}{l}\text { Cardio- } \\
\text { vascular }\end{array}$ & Respiratory & $\begin{array}{l}\text { Lung } \\
\text { cancer }\end{array}$ & Other \\
\hline 1 & $1982-86$ & 393 & 80.9 & $1.52(-0.75 / 4.94)$ & 2092194 & 181848 & 107367 & 83964 & 23403 & 12277 & 62204 \\
\hline 2 & $1986-90$ & 206 & 81.6 & $2.64(0.07 / 5.49)$ & 1118292 & 98053 & 55088 & 43652 & 11436 & 6752 & 36213 \\
\hline 3 & 1990-94 & 185 & 77.8 & $2.76(0.20 / 5.26)$ & 1046952 & 88083 & 49652 & 37907 & 11745 & 6051 & 32380 \\
\hline 4 & 1994-98 & 118 & 80.0 & $2.76(0.13 / 5.12)$ & 662343 & 52792 & 29449 & 20978 & 8471 & 3473 & 19870 \\
\hline
\end{tabular}

Great Britain (1991): total number of wards $=10528$; urban land $=42.3 \%$; total population (30+ years) $=32508667$. 
Table 2 Percentage excess relative risks ( $95 \%$ credible intervals) by cause and exposure window (years) for black smoke (per $10 \mu \mathrm{g} / \mathrm{m}^{3}$ ) across all mortality periods combined

\begin{tabular}{|c|c|c|c|c|c|c|c|c|c|c|c|c|}
\hline \multirow{2}{*}{$\begin{array}{l}\text { Exposure } \\
\text { window } \\
\text { (years)* }^{*}\end{array}$} & \multicolumn{2}{|l|}{ All-cause } & \multicolumn{2}{|c|}{ Cardiorespiratory } & \multicolumn{2}{|c|}{ Cardiovascular } & \multicolumn{2}{|l|}{ Respiratory } & \multicolumn{2}{|l|}{ Lung cancer } & \multicolumn{2}{|l|}{ Other } \\
\hline & Unadjusted & Adjusted $t$ & Unadjusted & Adjustedt & Unadjusted & Adjusted $t$ & Unadjusted & Adjustedt & Unadjusted & Adjusted $t$ & Unadjusted & Adjustedt \\
\hline $0-4$ & $\begin{array}{l}3.8 \\
(3.4 \text { to } 4.1)\end{array}$ & $\begin{array}{l}1.3 \\
(1.0 \text { to } 1.6)\end{array}$ & $\begin{array}{l}4.4 \\
\text { (3.9 to } 4.8 \text { ) }\end{array}$ & $\begin{array}{l}1.7 \\
(1.3 \text { to } 2.2)\end{array}$ & $\begin{array}{l}3.9 \\
\text { (3.4 to } 4.4 \text { ) }\end{array}$ & $\begin{array}{l}1.2 \\
(0.7 \text { to } 1.7)\end{array}$ & $\begin{array}{l}6.0 \\
(5.1 \text { to } 6.9)\end{array}$ & $\begin{array}{l}3.6 \\
(2.6 \text { to } 4.5)\end{array}$ & $\begin{array}{l}4.5 \\
\text { (3.3 to } 5.8)\end{array}$ & $\begin{array}{l}0.4 \\
(-0.9 \text { to } 1.7)\end{array}$ & $\begin{array}{l}2.7 \\
(2.1 \text { to } 3.2)\end{array}$ & $\begin{array}{l}0.8 \\
(0.2 \text { to } 1.4)\end{array}$ \\
\hline $5-8$ & $\begin{array}{l}3.2 \\
(3.0 \text { to } 3.5)\end{array}$ & $\begin{array}{l}1.3 \\
(1.0 \text { to } 1.5)\end{array}$ & $\begin{array}{l}3.7 \\
(3.3 \text { to } 4.0 \text { ) }\end{array}$ & $\begin{array}{l}1.6 \\
(1.2 \text { to } 1.9)\end{array}$ & $\begin{array}{l}3.3 \\
(2.9 \text { to } 3.6)\end{array}$ & $\begin{array}{l}1.1 \\
(0.8 \text { to } 1.5)\end{array}$ & $\begin{array}{l}5.0 \\
(4.4 \text { to } 5.7)\end{array}$ & $\begin{array}{l}3.1 \\
(2.4 \text { to } 3.9)\end{array}$ & $\begin{array}{l}4.8 \\
\text { (3.9 to } 5.7 \text { ) }\end{array}$ & $\begin{array}{l}1.4 \\
(0.4 \text { to } 2.4)\end{array}$ & $\begin{array}{l}2.2 \\
(1.8 \text { to } 2.6)\end{array}$ & $\begin{array}{l}0.7 \\
(0.3 \text { to } 1.2)\end{array}$ \\
\hline $9-12$ & $\begin{array}{l}2.6 \\
(2.4 \text { to } 2.7)\end{array}$ & $\begin{array}{l}1.2 \\
(1.0 \text { to } 1.3)\end{array}$ & $\begin{array}{l}2.9 \\
(2.8 \text { to } 3.1)\end{array}$ & $\begin{array}{l}1.5 \\
(1.3 \text { to } 1.8)\end{array}$ & $\begin{array}{l}2.8 \\
(2.6 \text { to } 3.0)\end{array}$ & $\begin{array}{l}1.4 \\
(1.2 \text { to } 1.6)\end{array}$ & $\begin{array}{l}3.4 \\
(3.1 \text { to } 3.8 \text { ) }\end{array}$ & $\begin{array}{l}2.0 \\
(1.6 \text { to } 2.5)\end{array}$ & $\begin{array}{l}4.4 \\
(3.9 \text { to } 5.0)\end{array}$ & $\begin{array}{l}1.9 \\
\text { (1.3 to } 2.4)\end{array}$ & $\begin{array}{l}1.6 \\
(1.3 \text { to } 1.8)\end{array}$ & $\begin{array}{l}0.4 \\
(0.2 \text { to } 0.7)\end{array}$ \\
\hline $13-16$ & $\begin{array}{l}2.0 \\
(1.9 \text { to } 2.0)\end{array}$ & $\begin{array}{l}0.9 \\
(0.8 \text { to } 1.0)\end{array}$ & $\begin{array}{l}2.2 \\
(2.0 \text { to } 2.4)\end{array}$ & $\begin{array}{l}1.3 \\
(1.2 \text { to } 1.4)\end{array}$ & $\begin{array}{l}2.2 \\
(2.1 \text { to } 2.4)\end{array}$ & $\begin{array}{l}1.3 \\
(1.2 \text { to } 1.4)\end{array}$ & $\begin{array}{l}2.4 \\
(2.1 \text { to } 2.6)\end{array}$ & $\begin{array}{l}1.2 \\
(0.9 \text { to } 1.5)\end{array}$ & $\begin{array}{l}3.2 \\
(2.8 \text { to } 3.5)\end{array}$ & $\begin{array}{l}1.1 \\
(0.8 \text { to } 1.5)\end{array}$ & $\begin{array}{l}1.2 \\
(1.0 \text { to } 1.3)\end{array}$ & $\begin{array}{l}0.3 \\
(0.2 \text { to } 0.5)\end{array}$ \\
\hline $0-8$ & $\begin{array}{l}1.9 \\
(1.8 \text { to } 2.1)\end{array}$ & $\begin{array}{l}0.7 \\
(0.6 \text { to } 0.9)\end{array}$ & $\begin{array}{l}2.2 \\
(2.0 \text { to } 2.4)\end{array}$ & $\begin{array}{l}0.9 \\
(0.7 \text { to } 1.1)\end{array}$ & $\begin{array}{l}2.0 \\
(1.7 \text { to } 2.2)\end{array}$ & $\begin{array}{l}0.7 \\
(0.4 \text { to } 0.9)\end{array}$ & $\begin{array}{l}3.0 \\
(2.6 \text { to } 3.4)\end{array}$ & $\begin{array}{l}1.9 \\
(1.5 \text { to } 2.3)\end{array}$ & $\begin{array}{l}2.6 \\
(2.1 \text { to } 3.2)\end{array}$ & $\begin{array}{l}0.6 \\
(0.0 \text { to } 1.2)\end{array}$ & $\begin{array}{l}1.3 \\
(1.1 \text { to } 1.6)\end{array}$ & $\begin{array}{l}0.4 \\
(0.2 \text { to } 0.7)\end{array}$ \\
\hline $0-12$ & $\begin{array}{l}1.3 \\
(1.2 \text { to } 1.3)\end{array}$ & $\begin{array}{l}0.5 \\
(0.5 \text { to } 0.6)\end{array}$ & $\begin{array}{l}1.4 \\
\text { (1.4 to } 1.5)\end{array}$ & $\begin{array}{l}0.7 \\
(0.6 \text { to } 0.8)\end{array}$ & $\begin{array}{l}1.3 \\
\text { (1.2 to } 1.5)\end{array}$ & $\begin{array}{l}0.6 \\
(0.5 \text { to } 0.7)\end{array}$ & $\begin{array}{l}1.8 \\
(1.6 \text { to } 2.0)\end{array}$ & $\begin{array}{l}1.1 \\
\text { (0.9 to } 1.3 \text { ) }\end{array}$ & $\begin{array}{l}2.0 \\
(1.7 \text { to } 2.3)\end{array}$ & $\begin{array}{l}0.7 \\
(0.4 \text { to } 1.0)\end{array}$ & $\begin{array}{l}0.8 \\
(0.7 \text { to } 0.9)\end{array}$ & $\begin{array}{l}0.3 \\
(0.1 \text { to } 0.4)\end{array}$ \\
\hline 0-16 & $\begin{array}{l}0.9 \\
(0.8 \text { to } 0.9)\end{array}$ & $\begin{array}{l}0.4 \\
(0.4 \text { to } 0.4)\end{array}$ & $\begin{array}{l}1.0 \\
(0.9 \text { to } 1.1)\end{array}$ & $\begin{array}{l}0.5 \\
(0.5 \text { to } 0.6)\end{array}$ & $\begin{array}{l}1.0 \\
(0.9 \text { to } 1.0)\end{array}$ & $\begin{array}{l}0.5 \\
(0.4 \text { to } 0.6)\end{array}$ & $\begin{array}{l}1.1 \\
(1.0 \text { to } 1.3)\end{array}$ & $\begin{array}{l}0.6 \\
(0.5 \text { to } 0.8)\end{array}$ & $\begin{array}{l}1.4 \\
(1.2 \text { to } 1.5)\end{array}$ & $\begin{array}{l}0.5 \\
(0.3 \text { to } 0.7)\end{array}$ & $\begin{array}{l}0.5 \\
(0.5 \text { to } 0.6)\end{array}$ & $\begin{array}{l}0.2 \\
(0.1 \text { to } 0.2)\end{array}$ \\
\hline
\end{tabular}

* See fig 1.

†Adjusted for deprivation and urban/rural classification.

extended to incorporate spatially structured random effects. We modelled the correlation in mortality between wards as an inverse exponential function of distance ${ }^{1721}$ based on the ward centroids; data were geographically too sparse to support the use of more complex models.

\section{RESULTS}

The characteristics of the wards meeting the selection criteria are summarised in table 1. Study wards were both more urbanised and more deprived than the national average: 78$82 \%$ of study wards were classified as urban compared with $42 \%$ nationally, while median Carstairs scores over the four health periods were equivalent to the $73 \mathrm{rd}$, 80th, 81 st and $81 \mathrm{st}$ percentiles nationally in a ranking of wards from least to most deprived. Study populations ranged from over 2 million for the first mortality period to 660000 for 1994-8. A total of 420776 deaths were included.

\section{Variations in air pollutant concentrations}

Air pollution concentrations in the study wards declined over the study period: mean (SD) BS concentrations fell from 74.9 (44.7) $\mu \mathrm{g} / \mathrm{m}^{3}$ in $1966-70$ to $13.3(5.3) \mu \mathrm{g} / \mathrm{m}^{3}$ in $1990-4 ; \mathrm{SO}_{2}$ concentrations declined from 41.4 (17.9) ppb to 12.2 (4.8) ppb. Variance components analysis indicated that within-ward variability (based on wards containing multiple monitoring sites) for each pollutant accounted for approximately 5\% of total variation compared with $20 \%$ between wards and $75 \%$ between years. The spatial pattern of air pollution remained relatively constant over time: correlation coefficients (R) between consecutive 4 year exposure windows were $0.8-0.9$ for both pollutants compared with $0.5-0.7$ for exposure windows starting 12 years apart. For 57 pairs of sites in wards with multiple sites running concurrently for at least 10 years, annual BS concentrations had correlations of 0.49-0.99 (mean $\mathrm{R}=0.81$ ) and coefficients of variation (CV) of 7.7-49.9\% (mean $\mathrm{CV}=20 \%$ ). For 41 pairs of sites for $\mathrm{SO}_{2}$ the equivalent statistics were $\quad \mathrm{R}=0.31-0.97 \quad($ mean $=0.87), \quad \mathrm{CV}=5.9-51.0 \%$ $($ mean $=25.5 \%)$. BS and $\mathrm{SO}_{2}$ concentrations were correlated across wards: $\mathrm{R}=0.62$ (exposure window 1966-70), 0.51 (1970-4), 0.47 (1974-8), 0.54 (1978-82), 0.59 (1982-6), 0.62 (1986-90) and 0.66 (1990-4).

Associations between social deprivation and air pollution changed over this period. For the first four exposure windows (1966-70 to 1982-6), concentrations of both BS and $\mathrm{SO}_{2}$ were significantly higher in more deprived wards than in less deprived wards $(p<0.03)$, after which there were no significant differences. There were also no differences in concentrations between urban and rural wards, except for $\mathrm{SO}_{2}$ in the first three

Table 3 Percentage excess relative risks ( $95 \%$ credible intervals) by cause and exposure window (years) for sulphur dioxide (per $10 \mathrm{ppb}$ ) across all mortality periods combined

\begin{tabular}{|c|c|c|c|c|c|c|c|c|c|c|c|c|}
\hline \multirow{2}{*}{$\begin{array}{l}\text { Exposure } \\
\text { window } \\
\text { (years)* }^{*}\end{array}$} & \multicolumn{2}{|l|}{ All-cause } & \multicolumn{2}{|c|}{ Cardiorespiratory } & \multicolumn{2}{|c|}{ Cardiovascular } & \multicolumn{2}{|l|}{ Respiratory } & \multicolumn{2}{|l|}{ Lung cancer } & \multicolumn{2}{|l|}{ Other } \\
\hline & Unadjusted & Adjustedt & Unadjusted & Adjustedt & Unadjusted & Adjustedt & Unadjusted & Adjustedt & Unadjusted & Adjustedt & Unadjusted & Adjusted† \\
\hline $0-4$ & $\begin{array}{l}6.8 \\
(6.3 \text { to } 7.4)\end{array}$ & $\begin{array}{l}4.2 \\
(3.6 \text { to } 4.8 \text { ) }\end{array}$ & $\begin{array}{l}8.0 \\
(7.3 \text { to } 8.8)\end{array}$ & $\begin{array}{l}5.2 \\
(4.4 \text { to } 6.0)\end{array}$ & $\begin{array}{l}6.0 \\
(5.2 \text { to } 6.9)\end{array}$ & $\begin{array}{l}3.0 \\
(2.2 \text { to } 3.9)\end{array}$ & $\begin{array}{l}15.1 \\
\text { (13.3 to } 16.6)\end{array}$ & $\begin{array}{l}13.2 \\
(11.5 \text { to } 14.9)\end{array}$ & $\begin{array}{l}5.2 \\
(3.0 \text { to } 7.3 \text { ) }\end{array}$ & $\begin{array}{l}-0.2 \\
(-2.4 \text { to } 2.0)\end{array}$ & $\begin{array}{l}5.2 \\
(4.3 \text { to } 6.2)\end{array}$ & $\begin{array}{l}3.5 \\
(2.5 \text { to } 4.4)\end{array}$ \\
\hline $5-8$ & $\begin{array}{l}7.5 \\
(7.1 \text { to } 7.9)\end{array}$ & $\begin{array}{l}4.4 \\
\text { (3.9 to } 4.8 \text { ) }\end{array}$ & $\begin{array}{l}7.8 \\
(7.2 \text { to } 8.3)\end{array}$ & $\begin{array}{l}4.5 \\
\text { (3.9 to } 5.1)\end{array}$ & $\begin{array}{l}6.2 \\
(5.5 \text { to } 6.8)\end{array}$ & $\begin{array}{l}2.9 \\
(2.2 \text { to } 3.5)\end{array}$ & $\begin{array}{l}13.5 \\
\text { (12.2 to } 14.8)\end{array}$ & $\begin{array}{l}10.5 \\
(9.2 \text { to } 11.9)\end{array}$ & $\begin{array}{l}9.6 \\
(7.8 \text { to } 11.3)\end{array}$ & $\begin{array}{l}3.2 \\
(1.5 \text { to } 4.9)\end{array}$ & $\begin{array}{l}6.7 \\
(5.9 \text { to } 7.4)\end{array}$ & $\begin{array}{l}4.4 \\
\text { (3.7 to } 5.2 \text { ) }\end{array}$ \\
\hline $9-12$ & $\begin{array}{l}6.3 \\
(6.0 \text { to } 6.6)\end{array}$ & $\begin{array}{l}3.1 \\
(2.7 \text { to } 3.4)\end{array}$ & $\begin{array}{l}6.4 \\
(6.0 \text { to } 6.8)\end{array}$ & $\begin{array}{l}3.2 \\
(2.7 \text { to } 3.6)\end{array}$ & $\begin{array}{l}5.2 \\
(4.7 \text { to } 5.6)\end{array}$ & $\begin{array}{l}2.0 \\
(1.5 \text { to } 2.5)\end{array}$ & $\begin{array}{l}10.6 \\
(9.7 \text { to } 11.6)\end{array}$ & $\begin{array}{l}7.3 \\
\text { (6.4 to } 8.3 \text { ) }\end{array}$ & $\begin{array}{l}9.6 \\
(8.4 \text { to } 10.9)\end{array}$ & $\begin{array}{l}2.8 \\
(1.6 \text { to } 4.1)\end{array}$ & $\begin{array}{l}5.5 \\
(5.0 \text { to } 6.1)\end{array}$ & $\begin{array}{l}2.9 \\
(2.3 \text { to } 3.5)\end{array}$ \\
\hline $13-16$ & $\begin{array}{l}4.9 \\
(4.7 \text { to } 5.1)\end{array}$ & $\begin{array}{l}2.3 \\
(2.0 \text { to } 2.5)\end{array}$ & $\begin{array}{l}5.1 \\
(4.8 \text { to } 5.4)\end{array}$ & $\begin{array}{l}2.5 \\
(2.2 \text { to } 2.9)\end{array}$ & $\begin{array}{l}4.4 \\
\text { (4.1 to } 4.7 \text { ) }\end{array}$ & $\begin{array}{l}1.9 \\
(1.6 \text { to } 2.3)\end{array}$ & $\begin{array}{l}7.6 \\
(7.0 \text { to } 8.2)\end{array}$ & $\begin{array}{l}4.7 \\
(4.0 \text { to } 5.4)\end{array}$ & $\begin{array}{l}7.7 \\
(6.9 \text { to } 8.5)\end{array}$ & $\begin{array}{l}1.8 \\
(0.9 \text { to } 2.7)\end{array}$ & $\begin{array}{l}4.0 \\
\text { (3.6 to } 4.3 \text { ) }\end{array}$ & $\begin{array}{l}1.9 \\
(1.5 \text { to } 2.3)\end{array}$ \\
\hline $0-8$ & $\begin{array}{l}4.1 \\
\text { (3.8 to } 4.4 \text { ) }\end{array}$ & $\begin{array}{l}2.5 \\
(2.2 \text { to } 2.7)\end{array}$ & $\begin{array}{l}4.4 \\
(4.1 \text { to } 4.8)\end{array}$ & $\begin{array}{l}2.7 \\
(2.4 \text { to } 3.1)\end{array}$ & $\begin{array}{l}3.5 \\
\text { (3.1 to } 3.8 \text { ) }\end{array}$ & $\begin{array}{l}1.7 \\
(1.3 \text { to } 2.1)\end{array}$ & $\begin{array}{l}7.9 \\
(7.1 \text { to } 8.6)\end{array}$ & $\begin{array}{l}6.5 \\
(5.8 \text { to } 7.3)\end{array}$ & $\begin{array}{l}4.4 \\
(3.5 \text { to } 5.4)\end{array}$ & $\begin{array}{l}1.1 \\
(0.1 \text { to } 2.1)\end{array}$ & $\begin{array}{l}3.5 \\
(3.1 \text { to } 3.9)\end{array}$ & $\begin{array}{l}2.3 \\
(1.9 \text { to } 2.7)\end{array}$ \\
\hline $0-12$ & $\begin{array}{l}2.8 \\
(2.7 \text { to } 3.0)\end{array}$ & $\begin{array}{l}1.6 \\
\text { (1.4 to } 1.7)\end{array}$ & $\begin{array}{l}3.0 \\
(2.8 \text { to } 3.2 \text { ) }\end{array}$ & $\begin{array}{l}1.7 \\
(1.5 \text { to } 1.9)\end{array}$ & $\begin{array}{l}2.4 \\
(2.2 \text { to } 2.6)\end{array}$ & $\begin{array}{l}1.0 \\
(0.8 \text { to } 1.3)\end{array}$ & $\begin{array}{l}5.1 \\
(4.7 \text { to } 5.5)\end{array}$ & $\begin{array}{l}3.9 \\
(3.5 \text { to } 4.4)\end{array}$ & $\begin{array}{l}3.7 \\
\text { (3.2 to } 4.3 \text { ) }\end{array}$ & $\begin{array}{l}1.0 \\
(0.4 \text { to } 1.6)\end{array}$ & $\begin{array}{l}2.5 \\
(2.2 \text { to } 2.7)\end{array}$ & $\begin{array}{l}1.5 \\
(1.2 \text { to } 1.7)\end{array}$ \\
\hline $0-16$ & $\begin{array}{l}2.0 \\
(1.9 \text { to } 2.1)\end{array}$ & $\begin{array}{l}1.0 \\
(0.9 \text { to } 1.1)\end{array}$ & $\begin{array}{l}2.1 \\
(2.0 \text { to } 2.2)\end{array}$ & $\begin{array}{l}1.1 \\
(1.0 \text { to } 1.3)\end{array}$ & $\begin{array}{l}1.7 \\
(1.6 \text { to } 1.9)\end{array}$ & $\begin{array}{l}0.8 \\
(0.6 \text { to } 0.9)\end{array}$ & $\begin{array}{l}3.4 \\
(3.1 \text { to } 3.7)\end{array}$ & $\begin{array}{l}2.4 \\
(2.2 \text { to } 2.7)\end{array}$ & $\begin{array}{l}2.9 \\
(2.5 \text { to } 3.2)\end{array}$ & $\begin{array}{l}0.7 \\
(0.4 \text { to } 1.1)\end{array}$ & $\begin{array}{l}1.7 \\
(1.5 \text { to } 1.9)\end{array}$ & $\begin{array}{l}0.9 \\
(0.8 \text { to } 1.1)\end{array}$ \\
\hline
\end{tabular}

*See fig 1 .

†Adjusted for deprivation and urban/rural classification. 


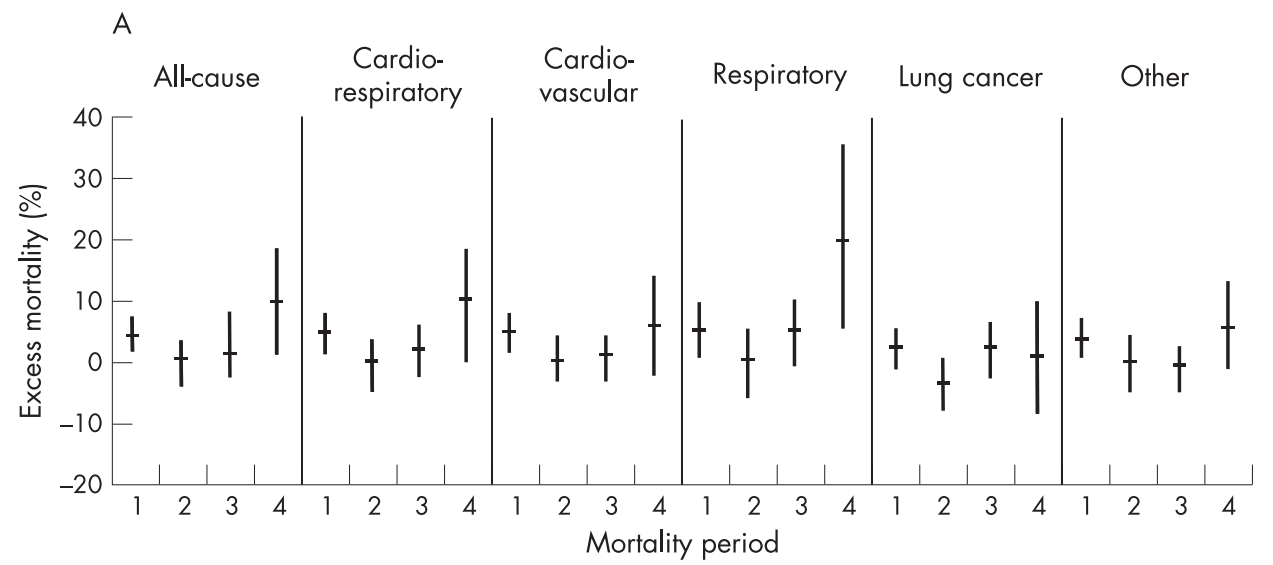

Figure 2 Excess relative risks for each mortality period with exposure data for the preceding $0-4$ years for (A) black smoke (per $10 \mu \mathrm{g} / \mathrm{m}^{3}$ ) and (B) sulphur dioxide (per $10 \mathrm{ppb})$. 1, earliest mortality period (19826); 4, most recent mortality period (1994-8).

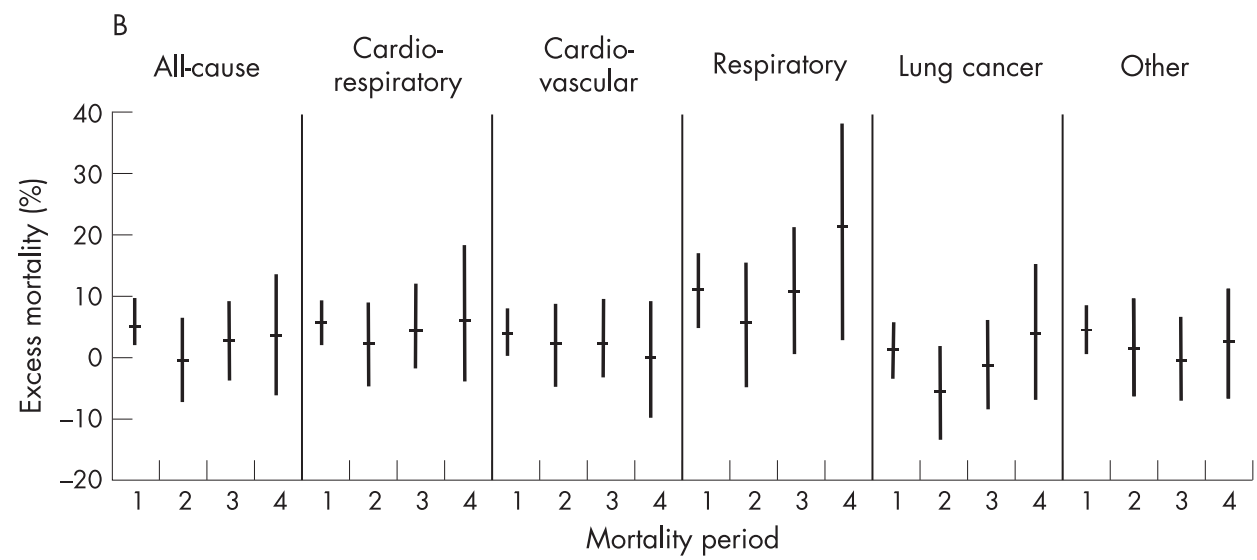

exposure windows when concentrations in urban wards were slightly higher than in rural wards.

\section{Excess risks for different exposure latencies}

Estimated excess relative risks (population age 30+ years) for a difference of $+10 \mu \mathrm{g} / \mathrm{m}^{3}$ in BS concentrations and $+10 \mathrm{ppb}$ in $\mathrm{SO}_{2}$ concentrations across all mortality periods combined for each exposure window are summarised in tables 2 and 3, respectively.

Unadjusted excess risks were positive and significant for both pollutants $(\mathrm{p}<0.05)$; they declined with increasing duration of exposure beyond $0-4$ years (ie, for $0-8,0-12$ and $0-16$ year exposure windows). For both pollutants adjustment reduced estimated risks, especially for lung cancer for which associations were no longer significant at $0-4$ years. For BS, excess risks tended to decline with increasing latencies for all outcomes except lung cancer; for $\mathrm{SO}_{2}$, excess risks were highest for the most proximal two exposure windows (0-4 and 58 years). When a spatial component was incorporated in the models, the estimated excess relative risks did not change but the credible intervals shrank slightly. For models containing both pollutants simultaneously, patterns for $\mathrm{SO}_{2}$ were similar although excess risks for BS were reduced (see table 1 in online supplement available at http://thorax.bmj.com/supplemental).

For both pollutants the largest excess relative risks were found for respiratory mortality. For the 0-4 year exposure window, adjusted excess relative risks were 3.6\% (95\% CI $2.6 \%$ to $4.5 \%)$ per $10 \mu \mathrm{g} / \mathrm{m}^{3}$ for BS and $13.2 \%$ (95\% CI $11.5 \%$ to $14.9 \%)$ per $10 \mathrm{ppb}$ for $\mathrm{SO}_{2}$. When we included both pollutants together, adjusted excess risk at $30+$ years for BS fell to $-0.7 \%$ (95\% CI $-1.7 \%$ to $0.4 \%$ ) while that for $\mathrm{SO}_{2}$ rose marginally to $13.9 \%$ (95\% CI $12 \%$ to $15.9 \%$ ) (see table 1 in online supplement available at http://thorax.bmj.com/supplemental). Repeating the single pollutant models for the $0-4$ year exposure window for the population aged $65+$ years (which accounted for $90 \%$ of deaths) gave almost identical estimates of excess risk for both pollutants (see table 2 in online supplement available at http:// thorax.bmj.com/supplemental).

\section{Excess risks by mortality period}

Figure 2 shows adjusted excess relative risks (age 30+ years) by mortality period for the preceding 0-4 year exposure window. Risks were significantly raised in the first mortality period (1982-6) for each cause of death other than lung cancer and, for BS, also in the most recent period (1994-8) for all causes, cardiorespiratory and respiratory mortality (respiratory only for $\mathrm{SO}_{2}$ ). For both pollutants the largest excess relative risks were found for respiratory mortality in the 1994-8 period: for BS the mean estimate was $19.3 \%$ (95\% credible interval $5.1 \%$ to $35.7 \%$ ) per $10 \mu \mathrm{g} / \mathrm{m}^{3}$ and for $\mathrm{SO}_{2}$ it was $21.7 \%$ (2.9\% to $\left.38.5 \%\right)$ per $10 \mathrm{ppb}$; with both pollutants considered together the excess risk reduced to $8.4 \%$ (95\% CI $-9.5 \%$ to $16.6 \%$ ) for BS and $17.8 \%$ (95\% CI $1.1 \%$ to $43.8 \%$ ) for $\mathrm{SO}_{2}$. There was no evidence that excess risks were greater in the more deprived areas. Tests of interaction with deprivation were non-significant for BS in all mortality periods; for $\mathrm{SO}_{2}$ there was one significant interaction $(p=0.02)$ for the first mortality period, but this reflected higher mortality in the less deprived decile of wards (see tables 3 and 4 in online supplement available at http://thorax.bmj.com/supplemental). There was also no significant interaction with sex for any of the four mortality periods, although excess risks tended to be slightly higher among men than women.

Regressions of adjusted excess relative risks of respiratory disease mortality against $\mathrm{BS}$ and $\mathrm{SO}_{2}$ concentrations (0-4 years exposure window) by mortality period showed the steepest regression lines in the most recent period (fig 3 posted online only, see http://thorax.bmj.com/supplemental). We repeated the main analyses on the set of 63 wards that were included 
throughout the study period (not shown). Compared with the full set of wards, these 63 wards showed no significant differences by surface area, population density, socioeconomic status or urban-rural classification. As for the main analyses, excess relative risks for both pollutants tended to be highest in the most recent mortality period and to decline with increasing latency.

\section{DISCUSSION}

Significant excess relative risks of mortality were found to be associated with long-term exposures to $\mathrm{BS}$ and $\mathrm{SO}_{2}$ across electoral wards in Great Britain. The risks were largest for respiratory mortality in the most recent period (1994-8) and with the most proximal measure of exposure (0-4 years). Larger effects also tended to be seen at lower pollutant concentrations, echoing results from acute studies ${ }^{27}$ and arguing against a threshold in the exposure-response relationship.

Our results are broadly consistent with those from other recent studies that used individual or semi-individual designs. For $\mathrm{SO}_{2}$, the largest to date is the American Cancer Society (ACS) study across 151 cities in the USA. ${ }^{17}{ }^{21-23}$ Re-analysis of the ACS data ${ }^{17}$ gave significant excess risks of all-cause mortality of $5 \%$ per $10 \mathrm{ppb} \mathrm{SO}_{2}, 6 \%$ for cardiorespiratory mortality and $5 \%$ for all other causes compared with $4.2 \%, 5.2 \%$ and $3.5 \%$ in our study (all mortality periods, $0-4$ year exposure window). In contrast, no significant increases were seen for allcause or cardiorespiratory mortality in the Seventh-Day Adventists Cohort Study in the USA or the PAARC study in France, ${ }^{5}{ }^{15}$ nor for all-cause mortality in the follow-up of 17000 adult men in Oslo. ${ }^{10}$ The Seventh-Day Adventists Study did report a large excess risk for lung cancer although no excess risk of lung cancer was seen in the Oslo cohort. ${ }^{59}$

Black smoke has generally not been investigated in the USA, where studies of particulates have focused on particle mass. In Europe the Dutch cohort study ${ }^{7}$ found a $17 \%$ (95\% CI $-24 \%$ to $78 \%$ ) adjusted excess risk for all-cause mortality per $+10 \mu \mathrm{g} / \mathrm{m}^{3}$ higher background concentrations of BS, and a $32 \%(95 \%$ CI $-2 \%$ to $78 \%$ ) excess for background plus local (ie, trafficrelated) concentrations. For cardiorespiratory mortality the excess risks were $34 \%$ (95\% CI $-32 \%$ to $164 \%$ ) and $71 \%(95 \%$ CI $10 \%$ to $167 \%$ ), respectively. The few other studies of BS reported in recent years have found lower risk estimates (with narrower confidence intervals). The PAARC study reported a $7 \%$ (95\% CI $3 \%$ to $10 \%$ ) excess for all-cause mortality but no significant excess for cardiorespiratory mortality or lung cancer across 18 areas in France; when an additional six areas affected by local traffic were included, the observed risks were reduced. ${ }^{15}$

We found that the effects of $\mathrm{SO}_{2}$ predominated over $\mathrm{BS}$ in joint models; in the ACS re-analysis, coefficients for fine particles were also markedly reduced when $\mathrm{SO}_{2}$ was included as a covariate, ${ }^{17}$ although in the Seventh-Day Adventists Study no change was reported in the regression coefficients for PM with $\mathrm{SO}_{2}$ included, implying that they had independent effects. ${ }^{5}$ Our findings need to be interpreted with caution because of spatial co-linearity between the two pollutants and the possibility of differential measurement errors that might have favoured $\mathrm{SO}_{2}$ over BS.

\section{Latency and temporal effects}

The availability of long-term high resolution pollution data allowed us to explore latency effects and changes in the associations between air pollution and mortality over time. Other than for lung cancer, the effects on mortality were greater for the most proximal exposure windows than for longer latencies and for short (0-4 year) rather than longer (eg, 0-16 years) durations of exposure. For lung cancer the absence of excess risk for the 0-4 year exposure window may reflect the long latency time for this disease. Excess risks were also larger in the most recent mortality period than in earlier periods. These results echo findings for fine particulate matter in the ACS study in which higher relative risks were found for the more recent period of follow-up (1999-2000) compared with the earlier period $(1979-83)^{21}$ although, in long-term follow-up of the Six Cities Study, relative risks were comparable for 197489 and $1989-98 .^{18}$

Over the study period the concentrations of $\mathrm{BS}$ and $\mathrm{SO}_{2}$ fell markedly in Great Britain, largely as a result of the introduction of emission controls, economic restructuring and technological changes. ${ }^{28}$ At the same time the source contributions to BS have changed. Historically, the most important sources were from coal combustion in industry, domestic heating and power stations. Between 1970 and 2000 the contribution from coal combustion fell from $80 \%$ to $32 \%$ while that from vehicle diesel fuel rose from $9 \%$ to $44 \%{ }^{29}$ Reflecting these changes, the relationship between BS and both particle mass and particle number have changed as has the composition of the particles concerned..$^{30}$ Diesel particles, for example, are typically both finer than those from industrial sources and less black. Analysis of national emissions data ${ }^{29}$ shows that, while total emissions have declined since 1970, the ratio of $\mathrm{PM}_{10}$ to BS emissions has increased from approximately 0.5 to 0.7 . Reflecting this, BS concentrations have fallen more sharply than those of $\mathrm{PM}_{10}$ and it now makes up only about $30 \%$ of the $\mathrm{PM}_{10}$ fraction, the balance coming from nitrate aerosols. ${ }^{28-30}$ There is also limited evidence that, while PM concentrations have declined, particle number concentrations have stayed more or less constant or have declined only slightly over the last 15 years. ${ }^{30}$ The apparently higher excess risks per unit of BS seen in our study for later periods might thus be because each unit of BS now represents a larger mass concentration (and number) of particles than in the past. Equally, the changing composition of the particle fraction means that PM is now characterised by higher proportions of more toxic water soluble and bioreactive materials. ${ }^{31}$ Results from the Six Cities Study, ${ }^{32}$ for example, showed a $3.4 \%$ (95\% CI $1.7 \%$ to $5.2 \%$ ) increase in mortality associated with traffic-related $\mathrm{PM}_{2.5}$ compared with a $1.1 \%$ (95\% CI $0.3 \%$ to $2.0 \%$ ) increase for industrially derived $\mathrm{PM}_{2.5}$. Time-series studies have also reported higher coefficients for BS in Western European cities where diesel vehicles are more abundant than in Eastern Europe which is still dominated by coal combustion sources. ${ }^{33}{ }^{34}$ The stronger effects seen in more recent years might therefore be evidence of increasing toxicity of the primary (mainly diesel-related) component of fine particles compared with the industrial particles that have dominated in the past.

Similar issues arise in relation to $\mathrm{SO}_{2}$. In the UK this is measured as strong acidity. Historically, $\mathrm{SO}_{2}$ played an important role in sulphuric acid formation which, in turn, was the main contributor to atmospheric acidity. With the decline of coal burning, atmospheric acidity has declined but $\mathrm{SO}_{2}$ now acts as an important precursor for sulphate formation which is, in turn, implicated in secondary particle generation. ${ }^{35}$ The somewhat larger coefficients seen in our results for $\mathrm{SO}_{2}$ in more recent years might be because $\mathrm{SO}_{2}$ is now acting as a marker for sulphates, which Schwartz and $\mathrm{Neas}^{36}$ have suggested has a major role in explaining the health effects of particles. The evidence for this remains weak, ${ }^{37}$ however, and an alternative interpretation is that $\mathrm{SO}_{2}$ is acting as a more indirect proxy for secondary fine particles; although not reflected in BS concentrations, these contribute substantially to particle mass and, even more so, number.

Artefactual explanations for the higher apparent excess risks in the most recent periods and with shorter latency also need to 
be considered. While pollution levels declined markedly over the study period, there were smaller declines in mortality rates, although the spatial distribution of mortality remained largely unchanged. In later periods much the same variation in mortality rates was therefore being "explained" by an attenuated range in pollutant concentrations, potentially inflating the regression slope relating the two. The possibility of such artefactual effects may also hold true in other studies that used recent (or concurrent) data on air pollution where longer latencies might be involved and, as such, merits further investigation.

We found the strongest effect for respiratory mortality. The respiratory tract is the primary site of contact with airborne pollutants, and respiratory mortality is strongly implicated in the acute effects of air pollution. ${ }^{1}$ In the ACS study, in contrast, the excess relative risk of cardiorespiratory disease was primarily due to cardiovascular rather than respiratory disease. ${ }^{17}$ The mechanism for the effect of airborne pollutants on cardiorespiratory risk is the subject of intense research interest. ${ }^{38}$ A major focus is the occurrence of an inflammatory response and oxidative stress in the lung, ${ }^{39}$ activating specific transcription factors which upregulate the expression of genes for cytokines, chemokines and other proinflammatory mediators. ${ }^{40}$ Systemic effects may lead to increased coagulability, cytokine release and increased risk of cardiovascular events. ${ }^{40}$ Such mechanisms could explain the relative short latency of events noted in our study.

\section{Limitations}

The ecological nature of this study meant that we did not have access to individual level exposure data. The uneven distribution and locality-specific nature of the monitoring sites precluded application of interpolation techniques, such as kriging, ${ }^{41}$ to model small area variations in pollutant concentrations. Detailed land cover and emissions data were also not available for the study period, preventing the use of dispersion modelling or land use regression methods. ${ }^{41}{ }^{42}$ Instead, we measured concentrations from the monitoring sites in each ward. Wakefield and Shaddick ${ }^{43}$ have shown that, where the monitoring network is sparse relative to the study area, the use of predicted concentrations can produce serious bias in effect parameters because the number of monitors is not sufficient to characterise the concentration surface. Nonetheless, our approach has limitations because it implies that air pollution levels are relatively uniform in the area around the site. To the extent that this does not hold true, the effect estimates may be biased if the error structure is classical rather than Berkson. ${ }^{44}$ By restricting the analysis to electoral wards that contained a monitoring station, however, we reduced the potential for such errors: the small size of these wards (average area $7.4 \mathrm{~km}^{2}$ ) means that the exposure measures were much more localised than in previous studies that have used data from routine monitoring sites. ${ }^{13} 23$

We also had no access to individual data on potential confounders. This raises the possibility of ecological bias and residual confounding, although previous semi-individual studies have not indicated strong effects of confounders other than smoking $^{713142123}$ and the small area scale should help to reduce any such effects. ${ }^{44}$ Specifically, Pope et $a l^{23}$ have argued that results of semi-individual studies such as the ACS are consistent with those of ecological studies across populations in the USA $^{45}$ and are unlikely to have been affected by residual confounding. Although small area data were not available for the study period on specific behaviours and risk factors such as tobacco consumption (eg, from VAT returns) or diet, the Carstairs score-which was used to adjust for area level socioeconomic confounding-is highly correlated with smoking. ${ }^{46}$ This was evidenced here by the large reduction in excess risks for lung cancer after adjustment for deprivation. In addition, the Carstairs score for 2001 correlates with ward level measures of income, employment and education derived from the national Index of Multiple Deprivation $2004^{47}(R=0.94$, 0.84 and 0.77, respectively, across 10528 wards in England). We used an urban-rural classification of wards to adjust for well established differences in health between urban and rural areas. $^{48}$

Because monitoring has tended to be focused in areas with suspected air pollution, the study wards may have been more polluted than average. This cannot be confirmed directly because of lack of monitoring in other areas, but examination of the maps of $\mathrm{SO}_{2}$ distribution for the early 1970s, inferred from lichen studies, ${ }^{49}$ indicates that the study wards were generally in the upper $50 \%$ of the concentration range that pertained at that time. It is not to be expected that this would bias our results, however, as the risk estimates are based on comparisons of air pollution and mortality across the included wards, not across Great Britain as a whole.

The small area design, together with changes in the monitoring network and in the availability of pollution data for different exposure periods, means that the study populations were not fixed over time. However, results for the 63 wards that were included throughout the study period did not differ materially from those for all the wards considered. We relied on population estimates from a single point in time (1991 census) as annual small area population counts are not available, but denominator errors are likely to be small. Comparisons of population numbers between the 1991 and 2001 census for 1182 wards whose boundaries have not changed showed mean (SD) increases of 8 (10.4)\%, with smaller increases $(6.7 \%$ and $7.3 \%)$ in wards in the two most deprived quintiles nationally (which characterise our study population). Annual migration rates are also limited. Nationally, about $10 \%$ of people change address each year, but some $56 \%$ of this movement (1991 census) was within $5 \mathrm{~km}$ and inter-ward migration in the wards studied here is probably of the order of $2-3 \%$ per year.

\section{CONCLUSIONS}

In conclusion, our findings from the extensive British data add to the evidence that air pollution has long-term effects on mortality, and point to continuing public health risks even at the relatively lower levels of $\mathrm{BS}$ and $\mathrm{SO}_{2}$ that now occur. They thus have importance for policies on public health protection through regulation and control of air pollution.

\section{ACKNOWLEDGEMENTS}

The authors thank Amanda Fraser for help in preparing the air pollution data, Daniela Fecht for help in preparing and analysing the socioeconomic data and Dr Anna Hansell for comments on the research and the paper at various stages.

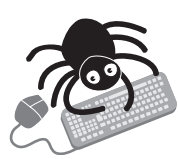

Further data are given in supplementary tables 1-4 and figure 3 available online at http://thorax.bmj. com/supplemental

\footnotetext{
Authors' affiliations

Paul Elliott, Gavin Shaddick, Jonathan C Wakefield, Cornelis de Hoogh, David J Briggs, Small Area Health Statistics Unit, Department of Epidemiology and Public Health, Faculty of Medicine, Imperial College London, UK

Gavin Shaddick, Department of Mathematical Sciences, University of Bath, UK
} 
Jonathan C Wakefield, Departments of Statistics and Biostatistics, University of Washington, USA

The Small Area Health Statistics Unit is funded by a grant from the Department of Health, Department of Environment, Food and Rural Affairs, Environment Agency, Scottish Executive, Welsh Assembly Government and the Northern Ireland Department of Health, Social Services and Public Safety. The funders approved the study design and commented on the results. Data analysis, interpretation and reporting were the sole responsibility of the authors. The views expressed in this publication are those of the authors and not necessarily those of the funding bodies.

Competing interests: None.

\section{REFERENCES}

1 Stieb DM, Judek S, Burnett RT. Meta-analysis of time-series studies of air pollution and mortality: effects of gases and particles and the influence of cause of death, age, and season. J Air Waste Manag Assoc 2002;52:470-84.

2 McMichael AJ, Anderson HR, Brunekreef B, et al. Inappropriate use of daily mortality analyses to estimate longer-term mortality effects of air pollution. Int J Epidemiol 1998;27:450-3.

3 Chinn S, Florey CD, Baldwin IG, et al. The relation of mortality in England and Wales 1969-73 to measurements of air pollution. J Epidemiol Community Health $1981 ; 35: 174-9$.

4 Ozkaynak H, Thurston GD. Associations between 1980 U.S. mortality rates and alternative measures of airborne particle concentration. Risk Anal 1987;7:449-61.

5 Abbey DE, Nishino N, McDonnell WF, et al. Long-term inhalable particles and other air pollutants related to mortality in nonsmokers. Am J Respir Crit Care Med 1999; 159:373-82

6 Finkelstein MM, Jerrett M, DeLuca $P$, et al. Relation between income, air pollution and mortality: a cohort study. CMAJ 2003;169:397-402.

7 Hoek G, Brunekreef B, Goldbohm S, et al. Association between mortality and indicators of traffic-related air pollution in the Netherlands: a cohort study. Lancet 2002;360: 1203-9.

8 Jerrett M, Burnett RT, Ma R, et al. Spatial analysis of air pollution and mortality in Los Angeles. Epidemiology 2005; 16:727-36.

9 Nafstad P, Haheim LL, Offedal B, et al. Lung cancer and air pollution: a 27 year follow up of 16209 Norwegian men. Thorax 2003;58:1071-6.

10 Nafstad P, Haheim LL, Wisleff T, et al. Urban air pollution and mortality in a cohort of Norwegian men. Environ Health Perspect 2004;112:610-5.

11 Rosenlund M, Berglind N, Pershagen G, et al. Long-term exposure to urban air pollution and myocardial infarction. Epidemiology 2006;17:383-90.

12 Kunzli N, Tager IB. The semi-individual study in air pollution epidemiology: a valid design as compared to ecologic studies. Environ Health Perspect 1997; 105:1078-83.

13 Dockery DW, Pope CA 3rd, Xu X, et al. An association between air pollution and mortality in six U.S. cities. N Engl J Med 1993;329:1753-9.

14 Enstrom JE. Fine particulate air pollution and total mortality among elderly Californians, 1973-2002. Inhal Toxicol 2005;17:803-16.

15 Filleul L, Rondeau V, Vandentorren S, et al. Twenty five year mortality and air pollution: results from the French PAARC survey. Occup Environ Med 2005:62:453-60.

16 Gehring U, Heinrich J, Krämer U, et al. Long-term exposure to ambient air pollution and cardiopulmonary mortality in women. Epidemiology 2006;17:545-51.

17 Krewski D, Burnett RT, Goldberg MS, et al. Reanalysis of the Harvard Six Cities Study and the American Cancer Society Study of Particulate Air Pollution and Mortality. Cambridge MA: Health Effects Institute, 2000; errata published, 2001

18 Laden F, Schwartz J, Speizer FE, et al. Reduction in fine particulate air pollution and mortality. Extended follow-up of the Harvard Six Cities Study. Am J Respir Crit Care Med 2006;173:667-72.

19 Lipfert FW, Morris SC. Temporal and spatial relations between age specific mortality and ambient air quality in the United States: regression results for counties, 1980-97. Occup Environ Med 2002;59:156-74.

20 Lipfert FW, Perry HM, Miller JP Jr, et al. Air pollution, blood pressure, and their long-term associations with mortality. Inhal Toxicol 2003;15:493-512.

21 Pope CA III, Burnett RT, Thun MJ, et al. Lung cancer, cardiopulmonary mortality, and long-term exposure to fine particulate air pollution. JAMA 2002;287: 1132-41.

22 Pope CA III, Burnett RT, Thurston GD, et al. Cardiovascular mortality and long term exposure to particulate air pollution: epidemiological evidence of general pathophysiological pathways of disease. Circulation 2004;109:71-7.
23 Pope CA III, Thun MJ, Namboodiri MM, et al. Particulate air pollution as a predictor of mortality in a prospective study of U.S. adults. Am J Respir Crit Care Med 1995;151:669-74

24 Nyberg F, Gustavsson P, Jarup L, et al. Urban air pollution and lung cancer in Stockholm. Epidemiology 2000;11:487-95.

25 Carstairs V. Socio-economic factors at areal level and their relationship with health. In: Elliott P, Wakefield J, Best N, et al, eds. Spatial epidemiology.Methods and applications. Oxford: Oxford University Press, 2000:51-67.

26 Fuller RM, Groom GB, Jones AR. The Land Cover Map of Great Britain: an automated classification of Landsat Thematic Mapper data. Photogrammetric Engineering Remote Sensing 1994;60:553-62.

27 Schwartz J. Is there harvesting in the association of airborne particles with daily deaths and hospital admissions? Epidemiology 2001;12:55-61.

28 Quality of Urban Air Review Group. Airborne particulate matter in the United Kingdom. Third Report of the QUARG, Institute of Public and Environmental Health, University of Birmingham, UK, Quality of the Urban Air Review Group, 1996.

29 Department for the Environment, Food and Rural Affairs. Digest of environmental statistics. London: Department for the Environment, Food and Rural Affairs, 2001, Available at:http://www2.defra.gov.uk/environment/ statistics/des/airqual/ch020210.htm\#Emissions.

30 Air Quality Expert Group. Particulate matter in the United Kingdom. London: Department for the Environment, Food and Rural Affairs, 2005.

31 Adamson IYR, Prieditis H, Vincent R. Pulmonary toxicity of an atmospheric particulate sample is due to the soluble fraction. Toxicol Appl Pharmacol 1999; 157:43-50

32 Laden F, Neas LM, Dockery DW, et al. Association of fine particulate matter from different sources with daily mortality in six U.S. cities. Environ Health Perspect 2000;108:941-7

33 Katsouyanni K, Touloumi G, Spix C, et al. Short-term effects of ambient sulphur dioxide and particulate matter on mortality in 12 European cities: results from time series data from the APHEA project. Air pollution and health: a European approach, BMJ 1997;314:1658-63.

34 Samoli E, Schwartz J, Woityniak B, et al. Investigating regional differences in short-term effects of air pollution on daily mortality in the APHEA project: a sensitivity analysis for controlling long-term trends and seasonality. Environ Health Perspect 2001;109:349-53.

35 Micallef A, Colls JJ. Analysis of long-term measurements of airborne concentrations of sulphur dioxide and $\mathrm{SO}_{4}{ }^{2-}$ in the rural United Kingdom. Environ Monit Assess 1999:57:277-90.

36 Schwartz J, Neas LM. Fine particles are more strongly associated than coarse particles with acute respiratory health effects in schoolchildren. Epidemiology 2000;11:6-10.

37 Loomis D. Sizing up air pollution research. Epidemiology 2000;1 1:2-4.

38 National Research Council, Committee on Research Priorities for Airborne Particulate Matter. Research priorities for airborne particulate matter. IV: Continuing research progress. Washington, DC: National Academies Press, 2004.

39 Kelly FJ. Oxidative stress: its role in air pollution and adverse health effects. Occup Environ Med 2003;60:61 2-6.

40 Brook RD, Franklin B, Cascio W, et al. Air pollution and cardiovascular disease. A statement for healthcare professionals from the Expert Panel on Population and Prevention Science of the American Heart Association. Circulation 2004; 109:2655-71

41 Briggs DJ. The role of GIS: coping with space (and time) in air pollution exposure assessment. J Toxicol Environ Health A 2005:68:1243-61.

42 Jerrett $M$, Arain A, Kanaroglou $P$, et al. A review and evaluation of intraurban air pollution exposure models. J Expo Anal Environ Epidemiol 2005; 15:185-204.

43 Wakefield J, Shaddick G. Health-exposure modeling and the ecological fallacy. Biostatistics 2006;7:438-55

44 Elliott $P$, Wakefield JC. Bias and confounding in spatial epidemiology. In: Elliott $P$, Wakefield J, Best N, Briggs DJ, eds. Spatial epidemiology:methods and applications. Oxford: Oxford University Press, 2000:68-84.

45 Lave LB, Seskin EP. Air pollution and human health. Science 1970;169:723-33

46 Kleinschmidt I, Hills M, Elliott P. Smoking behaviour can be predicted by neighbourhood deprivation measures. J Epidemiol Community Health 1995;49(Suppl 2):S72-7.

47 Noble M, Wright G, Dibben C, et al. The English indices of deprivation 2004 (revised). Technical report, Office of the Deputy Prime Minister, Neighbourhood Renewal Unit, London: ODPM Publications, 2004.

48 Verheij RA. Explaining urban-rural variations in health: a review of interactions between individual and environment. Soc Sci Med 1996;42:923-35.

49 Hawksworth DL, Rose F. Lichens as pollution monitors. London: Edward Arnold, 1976. 